\title{
First record of powdery mildew of castor- oil plant (Ricinus communis) caused by the anamorphic stage of Leveillula taurica in Iran
}

\author{
M. R. Mirzaee - S. A. Khodaparast - M. Mohseni • \\ S. H. R. Ramazani • M. Soltani-Najafabadi
}

Received: 21 October 2010 / Accepted: 15 February 2011/Published online: 22 May 2011

(C) Australasian Plant Pathology Society Inc. 2011

\begin{abstract}
In August 2010, leaves of Ricinus communis with typical symptoms of powdery mildew were collected in south Khorasan province, eastern Iran. The pathogen was identified as the anamorphs of Leveillula taurica. This is the first report of a powdery mildew on Ricinus in Iran.
\end{abstract}

\section{Keywords First reports $\cdot$ Leveillula taurica $\cdot$ Ricinus}

The castor- oil plant (Ricinus communis) is an annual herb or spreading shrub to about $6 \mathrm{~m}$ tall that belongs to the Euphorbiaceae. It is perennial in moist areas and annual in seasonally frosty or dry areas. It has been cultivated in Asia and Africa from ancient times. This plant is now widely naturalized in moist tropical and subtropical zones of the world (Francis 2004).

During a survey of plant pathogens conducted on $R$. communis in August 2010, typical symptoms of a powdery mildew disease were observed on nearly $10 \%$ of the plants

\section{R. Mirzaee $(\bowtie)$}

Agricultural and Natural Resources

Research Center of Southern Khorasan,

Birjand, PO Box 413, Iran

e-mail: reza.mirzaee.mrz@gmail.com

\section{S. A. Khodaparast}

Department of Plant Protection, College of Agriculture,

University of Guilan,

Rasht 41635-1314P.O.B. 41889, Iran

\section{Mohseni • S. H. R. Ramazani}

Agricultural Education Center of Southern Khorasan,

Birjand, Iran

M. Soltani-Najafabadi

Seed and Plant Improvement Institute,

Karaj, Iran

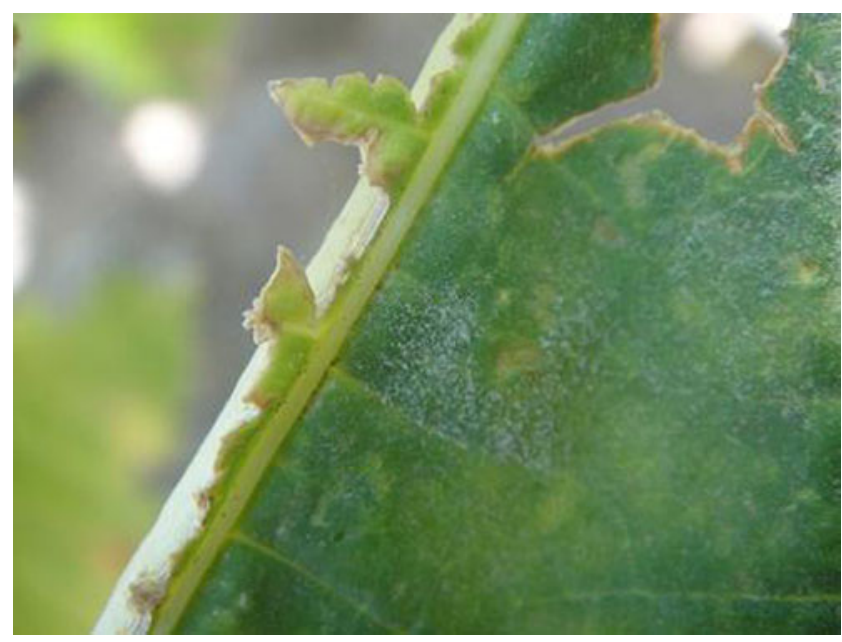

Fig. 1 Powdery mildew signs on upper leaf surface of Ricinus communis infected with Leveillula taurica

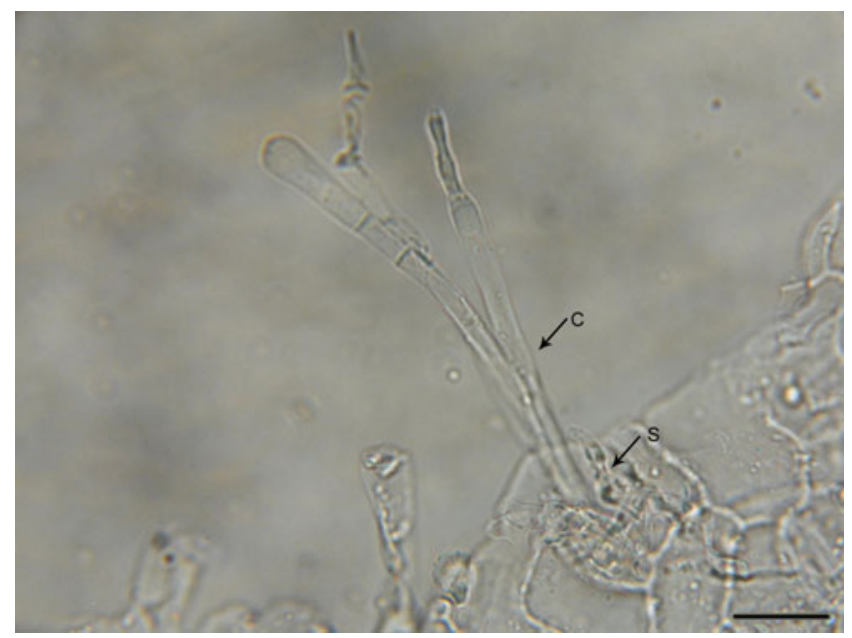

Fig. 2 Conidiophore (C) of Leveillula taurica emerging through a stoma (S). Bar $=50 \mu \mathrm{m}$ 


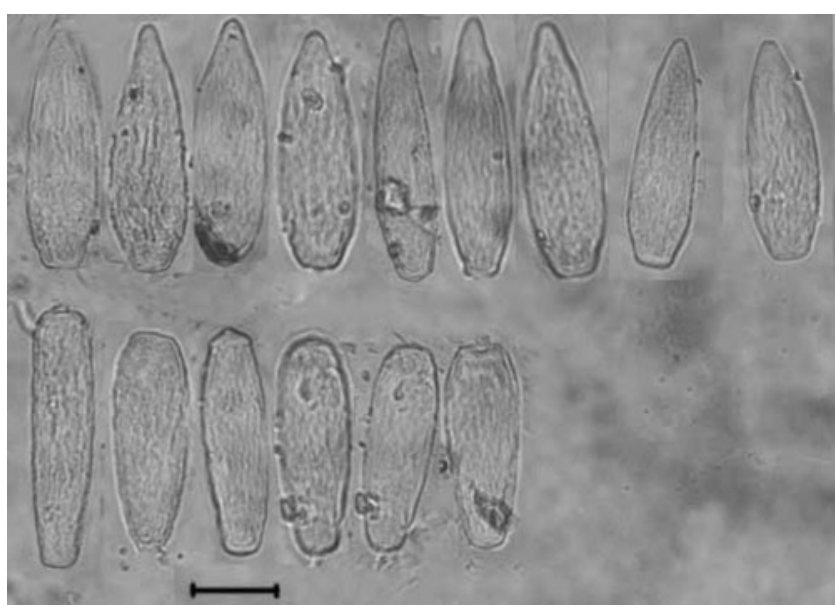

Fig. 3 Leveillula taurica on Ricinus communis. Primary (top) and secondary (bottom) conidia, Bar $=20 \mu \mathrm{m}$

in the surveyed area in the Mahammadiah region $\left(32^{\circ} 52^{\prime} \mathrm{N} /\right.$ $59^{\circ} 13^{\prime} \mathrm{E}$ ), south Khorasan province, eastern Iran. Symptoms included extensive abaxial cover of older leaves by white patches of external superficial mycelium and conidiophores, along with chlorotic and necrotic regions on the upper leaf surface. Colonies were also present on the upper leaf surface (Fig. 1). These symptoms were mainly observed on castoroil plants subjected to water deficiency stress, 2 weeks prior to harvest. However such symptoms were not observed in an ornamental castor- oil variety, planted close to the diseased plants. A sample was collected, dried and deposited in the herbarium at the Plant Pests and Diseases Research Institute (IRIPP) with voucher number IRAN $15030 \mathrm{~F}$.

Fungal structures were detached from the diseased leaves of with a razor blade, mounted in water or lactic acid and examined with a light microscope.

Conidiophores emerged through leaf stomata, singly or branched, usually in groups of two to three, and formed dimorphic conidia (Fig. 2). Examination of 50 of each type of conidia yielded the following description of their morphology: primary conidia lanceolate with distinct apical points, $12.5-19 \times 37.5-70 \mu \mathrm{m}$; secondary conidia cylindrical, $12.5-20 \times 37.5-77.5 \mu \mathrm{m}$; both conidia hyaline with angular/reticulated wrinkling of the outer walls (Figs. 3 and 4). These morphological features are typical of the anamorphic stage description of Leveillula taurica (Lév.) Arnaud (Braun 1987).

Leveillula taurica has been reported on $R$. communis worldwide [Ramakrishnan and Narasimhalu (1941), Chiddarwar (1954), Amano (Hirata) (1986), Farr and Rossman (2010)] but this is the first report of this powdery mildew species on Ricinus communis in Iran (Ershad 2009; Khodaparast and Abbasi 2009). Other recent records of $L$. taurica from Iran were published by Mirzaee et al. (2007) and Mirzaee and Mohammadi (2010).
Fig. 4 Leveillula taurica conidiophores: a) with a primary conidium and $\mathbf{b}$ ) with a secondary and cylindrical conidium. Bar $=20 \mu \mathrm{m}$
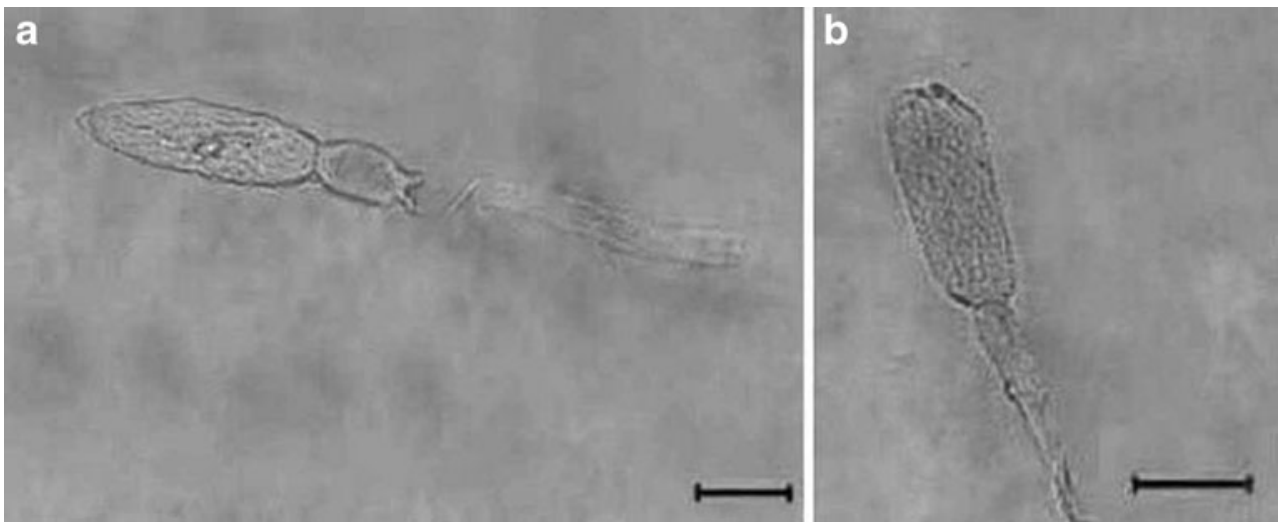


\section{References}

Amano (Hirata) K (1986) Host range and geographical distribution of the powdery mildew fungi. Japan Scientific Society Press, Tokyo, p 742

Braun U (1987) A monograph of the erysiphaceae (powdery mildews). Beiheftezur. Nowa Hedwigia 89:1-700

Chiddarwar PP (1954) Occurance of Oidiopsis taurica (Lev.) Salmon on a new host, Ricinus Communis L. Curr Sci 23:198

Ershad D (2009) Fungi of Iran, 2nd edn. Agricultural Research, Education and Extension Organization, Tehran

Farr DF, Rossman AY (2010) Fungal databases, systematic mycology and microbiology laboratory, ARS, USDA. Retrieved 30th December 2010, from http://nt.ars-grin.gov/fungaldatabases

Francis JK (2004) Ricinus communis L. Castor bean. In: Francis JK (ed.), Wildland shrubs of the United States and its territories: thamnic descriptions. San Juan, Puerto Rico and Fort Collins, CO: U.S. Department of Agriculture, Forest Service, International
Institute of Tropical Forestry and U.S. Department of Agriculture, Rocky Mountain Research Station; pp. 643-644. Available at http://www.fs.fed.us/global/iitf/pdf/shrubs/Ricinus\%20communis. pdf

Khodaparast SA, Abbasi M (2009) Species, host range and geographical distribution of powdery mildew fungi (Ascomycota: Erysiphales) in Iran. Mycotaxon 108: 213-216. Available at http:// staff.guilan.ac.ir/staff/users/khodaparastm/fckeditor_repo/file/ Checklist.pdf

Mirzaee MR, Abassi M, Nakhei A (2007) First report of powdery mildew on roselle caused by Leveillula taurica in Iran. Iran J Plant Pathol 43:478-479

Mirzaee MR, Mohammadi M (2010) Occurrence of powdery mildew caused by Leveillula taurica on onion (Allium cepa) in Iran. Plant Dis 94:280

Ramakrishnan TS, Narasimhalu IL (1941) A new host, Ricinus communis, for Leveillula taurica (Lev.) Arn. (Oidiopsis taurica (Lev.) Salm.). Curr Sci 10:211-212 